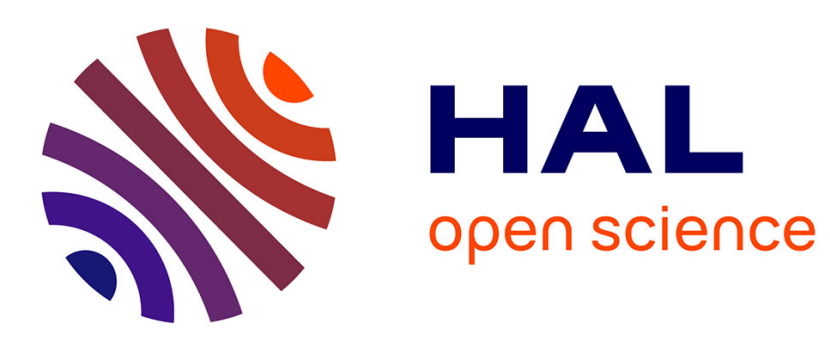

\title{
Mitochondrial dysfunction in pancreatic $\beta$-cells in type 2 diabetes
}

Hindrik Mulder, Charlotte Ling

\section{To cite this version:}

Hindrik Mulder, Charlotte Ling. Mitochondrial dysfunction in pancreatic $\beta$-cells in type 2 diabetes. Molecular and Cellular Endocrinology, 2008, 297 (1-2), pp.34. 10.1016/j.mce.2008.05.015 . hal00532029

\section{HAL Id: hal-00532029 \\ https://hal.science/hal-00532029}

Submitted on 4 Nov 2010

HAL is a multi-disciplinary open access archive for the deposit and dissemination of scientific research documents, whether they are published or not. The documents may come from teaching and research institutions in France or abroad, or from public or private research centers.
L'archive ouverte pluridisciplinaire HAL, est destinée au dépôt et à la diffusion de documents scientifiques de niveau recherche, publiés ou non, émanant des établissements d'enseignement et de recherche français ou étrangers, des laboratoires publics ou privés. 


\section{Accepted Manuscript}

Title: Mitochondrial dysfunction in pancreatic $\beta$-cells in type 2 diabetes

Authors: Hindrik Mulder, Charlotte Ling

PII: $\quad$ S0303-7207(08)00231-1

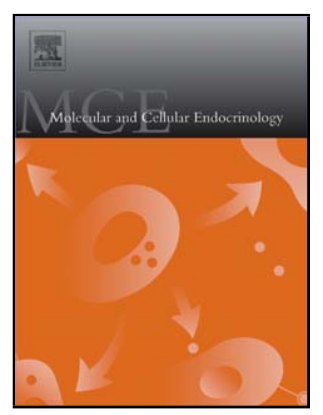

DOI: doi:10.1016/j.mce.2008.05.015

Reference: $\quad$ MCE 6887

To appear in: $\quad$ Molecular and Cellular Endocrinology

Received date: $\quad$ 5-2-2008

Revised date: $\quad 12-5-2008$

Accepted date: $\quad$ 23-5-2008

Please cite this article as: Mulder, H., Ling, C., Mitochondrial dysfunction in pancreatic $\beta$-cells in type 2 diabetes, Molecular and Cellular Endocrinology (2007), doi:10.1016/j.mce.2008.05.015

This is a PDF file of an unedited manuscript that has been accepted for publication. As a service to our customers we are providing this early version of the manuscript. The manuscript will undergo copyediting, typesetting, and review of the resulting proof before it is published in its final form. Please note that during the production process errors may be discovered which could affect the content, and all legal disclaimers that apply to the journal pertain. 


\title{
Mitochondrial dysfunction in pancreatic $\beta$-cells in type 2 diabetes
}

\author{
Hindrik Mulder*, and Charlotte Ling"
}

Department of Clinical Sciences in Malmö, Units of Molecular Metabolism*, and Endocrinology" at Lund University Diabetes Centre, Clinical Research Center, Malmö University Hospital, Lund University, Sweden

\footnotetext{
Corresponding author: Hindrik Mulder, MD, Ph.D

Unit of Molecular Metabolism

Department of Clinical Sciences in Malmö

Lund University Diabetes Centre

CRC 91:12

SE-205 02

Malmö Sweden

hindrik.mulder@med.lu.se
} 


\section{Abstract}

Mitochondrial metabolism controls insulin secretion from the pancreatic $\beta$-cell. Type 2 Diabetes evolves when the $\beta$-cells fail to release appropriate amounts of insulin, causing metabolic dysregulation and hyperglycemia. It is attractive to assume that mitochondrial dysfunction plays a decisive role in these processes. Indeed, while being a rare condition, genetically determined dysfunction of mitochondria causes a Type 2 Diabetes-like syndrome. Here, we review what is known about mitochondrial dysfunction in the $\beta$-cell in Type 2 Diabetes. The focus is on observations in humans but relevant studies in animal models of the disease are discussed. A particular emphasis is placed on changes in metabolic enzymes and function in $\beta$-cell mitochondria and how altered structure of the organelle appears to facilitate its function. These molecular processes are subject to tight genetic as well as epigenetic control. Variations and implications of these mechanisms are reviewed. The emerging picture is that alterations in mitochondria may be a culprit in the pathogenetic processes culminating in Type 2 Diabetes. Such processes may prove to be targets for therapeutic interventions in the disease.

Key words: TCA cycle - coupling signal - oxidative phosphorylation - mitochondrial biogenesis - epigenetics 


\section{Introduction}

There is now very strong support for the notion that failure of insulin secretion is ultimately the culprit in Type 2 Diabetes (Muoio and Newgard, 2008). During the last year a number of genome wide scans of patients with Type 2 Diabetes have been published (Saxena et al., 2007; Scott et al., 2007; Sladek et al., 2007; Zeggini et al., 2007). A recurring finding is that the genes, which are most strongly linked with the disease, all seem highly relevant for $\beta$-cell function and development. While this breakthrough knowledge is bound to change the way we view the pathogenesis of Type 2 Diabetes, still very little is known about how functional and structural abnormalities in islets lead to the impairment of insulin secretion that causes the human disease. The role of deficient $\beta$-cell mass in Type 2 Diabetes has been debated for decades (Ahrén, 2005); at the moment, the strongest data available suggest that there is indeed a loss of $\beta$-cell mass in Type 2 Diabetes, due to increased apoptosis (Butler et al., 2003). While this is most likely a fact, it can not by itself account for the perturbation of insulin secretion in the disease; $\beta$-cell loss in obese and lean individuals at most reaches $\sim 60$ and $40 \%$, respectively, compared with obese and lean non-diabetic individuals (Butler et al., 2003). Reasonably, if the observed loss of $\beta$-cell mass plays a role in the pathogenesis of Type 2 Diabetes, it does so in combination with a functional defect.

It is widely agreed that insulin secretion is largely controlled by metabolism of fuels, foremost glucose, in the pancreatic $\beta$-cell (Muoio and Newgard, 2008). Other factors, such as circulating hormones, paracrine and autocrine mechanisms, and neuronal (autonomic and sensory) control, all combine to modulate insulin secretion elicited by $\beta$-cell metabolism (Ahrén, 2000). In this process, mitochondria play a key role (Wollheim, 2000). Here, oxidation of most cellular fuels produces reducing equivalents, which drive the respiratory chain and subsequently ATP production via oxidative phosphorylation (OXPHOS). The rise in the ATP:ADP ratio closes the ATP-sensitive $\mathrm{K}^{+}$channel $\left(\mathrm{K}_{\mathrm{ATP}}\right)$, which results in depolarization of the plasma membrane, opening of voltage-gated $\mathrm{Ca}^{2+}$ channels and subsequently exocytosis. This pathway is known as $\mathrm{K}_{\mathrm{ATP}}$-dependent or triggering (Henquin, 2000). In addition, mitochondria are likely to play a critical role in the $\mathrm{K}_{\mathrm{ATP}}$-independent or 


\section{MULDER AND LING, MITOCHONDRIA AND TYPE 2 DiABETES}

amplifying pathway of insulin secretion (Maechler et al., 2006). Metabolites from mitochondria, reducing equivalents or metabolite fluxes dependent on these are believed to account for the sustained phase of insulin secretion (Prentki and Corkey, 1996), which can not be upheld by raised intracellular $\mathrm{Ca}^{2+}$ alone, i.e., the product of the triggering pathway. Thus, mitochondria take center stage in the control of insulin secretion, the deciding pathogenetic event in Type 2 Diabetes.

Moreover, also in the control of $\beta$-cell mass, mitochondria may play a critical role. The available data suggest that increased apoptosis underlies the loss of $\beta$-cell mass observed in islets from patients with Type 2 Diabetes (Butler et al., 2003; Trifunovic and Larsson, 2008). Indeed, the apoptotic pathways converge in mitochondria, where caspase- 3 activation and cytochrome $\mathrm{C}$ export precipate these events. Finally, aging is a determining factor in the pathogenesis of Type 2 Diabetes. Also in this process, there is a strong focus on mitochondrial metabolism (Lee et al., 2007; Ling et al., 2004; Ling et al., 2007; Trifunovic and Larsson, 2008). For all these reasons, mitochondria are a primary concern in the disease processes of Type 2 Diabetes. This review will describe what is known about the role of mitochondria in $\beta$-cells during the events leading to Type 2 Diabetes. We will focus on what is known from the human disease, but where relevant, also include observations from experimental models.

\section{Changes in mitochondrial metabolism in diabetes}

\section{$\beta$-cell mitochondrial metabolism in insulin resistant mice}

At this point, there is no information on how mitochondria in human $\beta$-cells adapt when an individual becomes insulin resistant. This is in stark contrast to all available data on how hyperinsulinemia evolves as an adaptive process to meet the increased demands for insulin to control whole body metabolism in the insulin resistant state (Abdul-Ghani et al., 2006). At the same time, an emerging research field is addressing the remarkable plasticity of the mitochondria as an organelle (Detmer and Chan, 2007). Mitochondria change their shape and 
the volume is altered, a plasticity which serves the purpose to optimize mitochondrial function and metabolism for every specific situation.

To study mitochondrial $\beta$-cell mitochondrial metabolism in insulin resistance, we employed C57BL/6J mice given a high fat diet. These mice become severely insulin resistant but do not develop frank diabetes (Ahrén et al., 1997), allowing studies of the normal processes that strive to adapt the pancreatic $\beta$-cell to the diabetogenic metabolic perturbations associated with impaired insulin sensitivity. Thus, in our hands, the C57BL/6J mice given a high fat diet exhibit basal hyperinsulinemia; an intravenous glucose tolerance test confirms retarded glucose disposal and increased amounts of insulin released during the challenge (Fex et al., 2007). Interestingly, insulin secretion from isolated islets in vitro revealed that while the glucose-stimulated insulin-response is blunted, responses to fuels mediating their effects via mitochondrial metabolism are exaggerated (Fig. 1A-B). This metabolic switch from glucose to other mitochondrial fuels is further confirmed by an exaggeration of oxidation of palmitate and glutamine, while glucose oxidation is impaired (Fig. 1C-E). The discrepancy between effects provoked by glucose and mitochondrial fuels could be explained by an impairment of GLUT2 localization that we observe, confirming previous findings (Reimer and Ahrén, 2002).

Our functional data suggest that mitochondrial metabolism is enhanced to compensate for restrained glucose metabolism in the insulin resistant state. This enhancement drives basal hyperinsulinemia and hypersecretion of insulin in vivo in the high fat diet-fed C57BL/6J mice. As a potential underlying mechanism, we found that whereas the number of mitochondria is unchanged, their mass is increased by $\sim 60 \%$. It is unclear how this enhancement of mitochondrial metabolism and mass is achieved. Lipid flux in the islets is increased, as shown by increased deposition of neutral lipids. We have examined expression of transcription factors and co-activators involved in mitochondrial biogenesis and control of metabolic enzymes and respiratory chain proteins, including peroxisome proliferatoractivated receptor $\gamma$ coactivator $1 \alpha$ (PGC-1 $\alpha)$, PGC-1 $\beta$, nuclear respiratory factor-1 (NRF-1) and mitochondrial transcription factor A (TFAM). In addition, expression levels of the nuclear-encoded mitochondrial protein cytochrome $\mathrm{C}$ and the mitochondria-encoded 
mitochondrial protein cytochrome c oxidase IV (COXIV) were analysed. None of these factors exhibited significant differences in mRNA expression levels during or after 12 weeks of high fat feeding.

\section{Mitochondrial dysfunction in C57BL/6J mice}

It was recently described that a strain of C57BL/6J mice, on normal diet, exhibits impaired glucose disposal, which could be attributed to perturbed insulin secretion (Toye et al., 2005). Islets are unresponsive to glucose but exhibit a normal rise in intracellular $\mathrm{Ca}^{2+}$ when stimulated by tolbutamide; similarly, their $\mathrm{K}_{\mathrm{ATP}}$-channels close in response to ATP. Collectively, these findings point towards a metabolic defect in pancreatic $\beta$-cells. Indeed, this strain was found to harbour a 5-exon deletion in the nicotinamide nucleotide transhydrogenase $(\mathrm{NNT})$ gene. The enzyme converts $\mathrm{NADP}^{+}$and NADH into NADPH and $\mathrm{NAD}^{+}$. It is associated with the respiratory chain, and has been suggested to protect mitochondria from an overload of reactive oxygen species (ROS), which could impair their function. Glutathione reductase requires NADPH to reduce glutathione, a component of the detoxifying mechanism.

Subsequent studies have confirmed that, when present, mutations in the nnt gene are associated with impaired glucose tolerance and insulin secretion in vivo (Freeman et al., 2006). Moreover, insulin secretion from islets is attenuated, ROS accumulate and there is loss of glucose-stimulated ATP production; knock down of nnt in MIN-6 cells by RNA interference impairs glucose-stimulated insulin secretion. Clearly, there is strong evidence for a role of nnt in $\beta$-cell stimulus-secretion coupling (Freeman et al., 2006; Toye et al., 2005). This further highlights the importance of $\beta$-cell mitochondrial metabolism in glucose homeostasis. However, all strains of C57BL/6J mice do not harbour this mutation. The 5-exon deletion is not present in the strain that we use (Fex et al., 2007), which was derived from the strain kept at the NIH Animal Genetic Resource, and embryo-derived into Taconic's facility; C57BL/6J mice are also available from lines kept at the Jackson Laboratory, and these were used in the studies on nnt (Toye et al., 2005). Thus, C57BL/6J strains are heterogeneous; a difference such as deletion in genes like nnt may explain why phenotypes in the different 
strains are variable. In this case, our C57BL/6J line is resistant to development of diabetes (Fex et al., 2007), whereas the one examined by Cox, Ashcroft and colleagues is diabetesprone without any challenge (Freeman et al., 2006; Toye et al., 2005).

\section{Mitochondrial changes in human $\beta$-cell in Type 2 Diabetes}

Since the access to human islets has increased as a consequence of the development of international centers of islet transplantation, there is now some limited information about islet function and mitochondrial alterations in human Type 2 Diabetes. A recent study of islets from 14 cadaveric donors with Type 2 Diabetes reported that the isolated islets are smaller and contain a reduced proportion of $\beta$-cells (Deng et al., 2004). Insulin secretion in response to glucose is impaired with respect to threshold, rate and total amount released. In contrast, the maximal response, as elicited by $\mathrm{KCl}$, is unchanged. The data thereby suggest that diabetic islets exhibit a specific metabolic impairment, since the secretory dysfunction is restricted to glucose.

The Pisa group examined insulin secretion and mitochondrial function in islets from seven donors that had documented Type 2 Diabetes (Anello et al., 2005). They confirm that glucose-stimulated, but not arginine-stimulated, insulin secretion is impaired in islets from individuals with Type 2 Diabetes. Again, this suggests the existence of a specific metabolic impairment in $\beta$-cells in Type 2 Diabetes. While ATP-levels in the basal state are actually elevated in Type 2 Diabetes islets, they fail to respond with a rise in the ATP:ADP ratio, an event thought to trigger insulin secretion. Moreover, glucose is less effective to hyperpolarize the mitochondrial membrane in the diabetic islets. The authors explain this finding with an increase $(+24 \%)$ in uncoupling protein-2 (UCP-2) levels. This protein is thought to uncouple the respiratory chain from ATP production by allowing protons to flow back into the mitochondrial matrix without giving rise to ATP. Interestingly, these functional alterations are paralleled by changes in mitochondrial structure. Thus, while there is no increase in mitochondrial number, their volume is increased, a finding reminiscent of what we reported in C57BL/6J mice on a high fat diet (Fex et al., 2007). Also expression of complex I and V is increased in the islets from patients with Type 2 Diabetes (Anello et al., 2005). 
These data are very interesting and clearly point towards a role for mitochondria in the pathology of islets in Type 2 Diabetes. Nevertheless, while some data support the role of UCP-2 in diabetes pathogenesis, others have raised concerns about whether the protein is indeed an uncoupler (Nicholls, 2006). It is unclear whether the modest increase of UCP-2 that was observed can account for such a profound effect on ATP production; clearly, much greater increases in UCP-2 expression were employed in the experimental studies where the protein was found to impair insulin secretion (Chan et al., 2001; Saleh et al., 2002). Moreover, changes in metabolism were not analyzed (Anello et al., 2005), and such changes could also have exerted the effects on ATP production that were observed.

\section{Structural dynamics and biogenesis of mitochondria}

It is becoming increasingly clear that the structure and number of mitochondria are subject to plasticity (Detmer and Chan, 2007; Mannella, 2006). If nothing else, the observations we have made in $\beta$-cells from insulin resistant mice (Fex et al., 2007) and others have made in human diabetic islets (Anello et al., 2005) underscore the importance of such alterations. These events are not arbitrary but highly regulated and serve to provide the cell with an organelle that is optimally functional in any given cellular state. An increase in the number of mitochondria is termed mitochondrial biogenesis. Such a change comes about by fission of pre-existing mitochondria; also the reverse, i.e., fusion of mitochondria occurs and is a means for regulation. In addition to these inter-mitochondrial alterations, changes within mitochondria are also observed (Mannella et al., 2001). Mainly fusion and fission of the inner mitochondrial membrane seem to occur, and have been proposed to play a functional role in the organelle; these structural changes may affect diffusion of protons as well as proteins (e.g., cytochrome C).

The heterogeneity and subsequent plasticity of mitochondria in $\beta$-cells have recently also been demonstrated functionally. While glucose and metabolism normally will hyperpolarize the mitochondrial membrane, a subpopulation of mitochondria exhibits a lower 
level of polarization; even depolarized mitochondria exist (Wikstrom et al., 2007). Glucose and methyl-succinate, a mitochondrial fuel, recruit mitochondria from this pool into a hyperpolarized one. Interestingly, under glucolipotoxic conditions, the proportion of mitochondria in the hyperpolarized population increases, suggesting that it may play a pathogenetic role under such conditions. Moreover, depolarized mitochondria may be more amenable to autophagocytosis (Twig et al., 2008), a process serving to clear the cell of dysfunctional constituents.

The mitofusin proteins 1 and 2 (MFN1/MFN2), which are localized to the outer mitochondrial membrane, together with the optic atrophy 1 (OPA1) protein, which is present on the inner mitochondrial membrane, are the key regulators of mitochondrial fusion events (Cipolat et al., 2004; Frezza et al., 2006). In mitochondrial fission, the cytosolic dynaminrelated protein 1 (DRP1) oligomerizes, and is recruited to the mitochondrion via an interaction with the outer membrane protein FIS1 (Lee et al., 2004; Zhang and Chan, 2007), resulting in the constriction and severing of the mitochondrion. In transcriptional control of mitochondria, PGC-1 $\alpha$ appears to be a master switch via co-activation of many nuclear receptors and other factors (Handschin and Spiegelman, 2006). Its control of mitochondrial biogenesis is mainly exerted by activation of NRF-1 and 2. TFAM is essential for transcription of the mitochondrial DNA (Ekstrand et al., 2004), a prerequisite for mitochondrial biogenesis. Interestingly, a conditional knock out of TFAM in $\beta$-cells results in impaired fuel-stimulated insulin secretion and diabetes in mice (Silva et al., 2000).

\section{Genetic and epigenetic regulation of mitochondria and association with Type 2 Diabetes}

\section{The mitochondrial genome and Diabetes}

That mitochondrial ATP production is a pre-requisite for fuel-stimulated insulin secretion is well established (Henquin, 2000; Muoio and Newgard, 2008; Wollheim, 2000). Oxidative phosphorylation and ATP production occur in a system consisting of five multiprotein complexes with 90 known protein subunits (Scarpulla, 2008). While the majority of these subunits are encoded by the nuclear genome, thirteen subunits are encoded by a circular 
double stranded DNA molecule, the 16.6-kb mitochondrial genome. Depletion of mitochondrial DNA (mtDNA) from $\beta$-cells results in impaired mitochondrial metabolism and loss of fuel-stimulated insulin secretion (Kennedy et al., 1996).

Rare mutations in mtDNA can cause mitochondrial dysfunction in humans and lead to $\beta$-cell dysfunction and subsequently diabetes (Maassen et al., 2005). The most frequent mutation targets bp 3243 in tRNA ${ }^{\text {Leu }}$, and is associated with Maternally Inherited Diabetes and Deafness (MIDD) or Mitochondrial Encephalopathy, Lactacidosis and Stroke (MELAS) (Goto et al., 1990; Reardon et al., 1992; van den Ouweland et al., 1992). It is not entirely clear why a mutation in the sequence for $\mathrm{tRNA}^{\mathrm{Leu}}$ causes mitochondrial dysfunction other than that the mutation disrupts expression and/or function of also other mitochondrial genes. Indeed, hybrid cells containing mitochondria with mutated DNA exhibit a number of metabolic impairments that may underlie defective stimulus-secretion coupling in $\beta$-cells (de Andrade et al., 2006). This is likely to explain perturbed glucose-stimulated insulin secretion in patients harbouring the mutations.

Great efforts have also been made to determine whether common variations in mtDNA are associated with impaired insulin secretion and Type 2 Diabetes. Indeed, a variant at position 16189 has been shown to be associated with elevated fasting insulin concentrations (Poulton et al., 2002; Poulton et al., 1998) and Type 2 Diabetes in a population-based casecontrol study (Poulton et al., 2002). However, other studies have been unable to replicate this association (Chinnery et al., 2005; Das et al., 2007; Mohlke et al., 2005). Moreover, another study aimed to capture the entire common variation (except the hypervariable D-loop) in mtDNA with a frequency $>1 \%$, and test if any of these variants are associated with Type 2 Diabetes (Saxena et al., 2006); 3304 cases and 3304 matched control subjects were examined. After adjustments for multiple testing, they did not find any significant association of common mtDNA variants and Type 2 Diabetes or related phenotypes, e.g., insulin secretion. In contrast, when polymorphisms in the coding region of the mtDNA were genotyped in Asian case-control cohorts, carriers of a haplogroup N9a display a significantly reduced risk of Type 2 Diabetes (Fuku et al., 2007). Thus, common variation in mtDNA does not seem to be a major pathogenetic factor, resulting in impaired $\beta$-cell function and increased risk of Type 2 Diabetes.

\section{Control of mitochondria by nuclear encoded genes}

Although several studies have investigated the association of common variation in mtDNA and risk of Type 2 Diabetes, it is less well established whether polymorphisms in nuclear- 
encoded OXPHOS genes confer susceptibility of Type 2 Diabetes and affect insulin secretion. NDUFB6 is a nuclear-encoded OXPHOS gene giving rise to a protein, which is part of complex 1 of the respiratory chain; it is significantly down-regulated in skeletal muscle from diabetic patients (Mootha et al., 2003). Therefore, we recently asked whether common variation in NDUFB6 is associated with risk of Type 2 Diabetes (Ling et al., 2007). We also examined whether an epigenetic factor, such as DNA methylation, may influence the expression of this gene. Cytosine residues occurring in CG dinucleotides are targets for DNA methylation. Normally, gene expression is reduced when DNA in a promoter is methylated. We found that carriers of the NDUFB6 rs540467 A/A genotype display a nominally increased risk of Type 2 Diabetes in two independent Scandinavian case-control cohorts (Ling et al., 2007). With respect to targets tissues of insulin, a polymorphism in the NDUFB6 promoter region, which creates a putative DNA methylation site ( $(\mathrm{ss} 629566, A / G)$, is associated with an age-related decline in muscle NDUFB6 expression (Ling et al., 2007). This is attributed to increased DNA methylation occurring in the promoter of elderly, but not young, subjects carrying the rs629566 $G / G$ genotype. Whether NDUFB6 is associated with changes also in insulin-secretion needs to be examined in future studies.

A host of studies has tested whether common variation in nuclear-encoded genes, with functions in or control of the mitochondria, confers risk of Type 2 Diabetes and/or influences $\beta$-cell function. The protein frataxin is responsible for the neurodegenerative disease Friedreich's ataxia: an intronic GAA-triplet expansion results in impaired expression of the protein, which is thought to play a role in the assembly of iron-sulphur complexes (Puccio and Koenig, 2000). Such complexes are found in respiratory chain proteins and aconitase. Not only do these patients develop a fatal neurological disorder, about one third of the patients also exhibits diabetes (Ristow, 2004). Moreover, several studies have shown linkage of Type 2 Diabetes with the locus containing the FRDA gene (9q13) (Lindgren et al., 2002). The underlying pathogenetic mechanisms have not been definitively resolved but mitochondrial dysfunction in $\beta$-cells as well as in target tissues of insulin could be anticipated. Indeed, $\beta$-cell specific knock out mice for frataxin develop insulin-dependent diabetes with loss of $\beta$-cell mass, due to cellular growth arrest and increased apoptosis, which are paralleled by an increase of ROS in islets (Ristow et al., 2003). Also deficient ATP production in skeletal muscle has been observed in humans (Lodi et al., 1999), which could contribute to impaired insulin sensitivity.

The transcriptional co-activator PGC-1 $\alpha$ is mapped to chromosomal region $4 \mathrm{p} 15.1$ that previously has been linked to fasting serum insulin concentrations in Pima Indians (Pratley 
et al., 1998). Furthermore, variants, such as Gly482Ser, of PGC-1 $\alpha$ are associated with Type

2 Diabetes and with indices of $\beta$-cell function in some, but not all, studies performed (Barroso et al., 2006; Ek et al., 2001; Hara et al., 2002; Lacquemant et al., 2002; Muller et al., 2003; Oberkofler et al., 2004; Sun et al., 2006; Vimaleswaran et al., 2005). In isolated rodent islets and clonal $\beta$-cells, overexpression of PGC- $1 \alpha$ suppresses insulin secretion (Yoon et al., 2003). We have shown that the PGC-1 $\alpha$ Gly482Ser variant influences the expression of this gene in human pancreatic islets (Ling et al., 2008) and in human skeletal muscle (Ling et al., 2004). We also demonstrated that expression of PGC- $1 \alpha$ is reduced in islets from patients with Type 2 Diabetes compared with control subjects and that the expression level correlates with glucose-stimulated insulin secretion. Indeed, our study is the first to demonstrate that epigenetic mechanisms are in operation in diabetic islets; this is based on the fact that the level of DNA methylation of the PGC- $1 \alpha$ promoter is increased in islets from patients with Type 2 Diabetes. The data show that combinations of genetic and epigenetic factors influence the level of PGC-1 $\alpha$ in human pancreatic islets, which subsequently may impair insulin secretion (Ling C, 2008) (Figure 2). At this point, the experimental in vitro work in some rodent models (Yoon et al., 2003), and our observations on genetic and epigenetic regulation of PGC- $1 \alpha$ in human pancreatic islets and its correlation with $\beta$-cell function do not agree. Clearly, more work in this important area needs to be performed.

Genetic variations in NRF-1 are associated with Type 2 Diabetes in a Korean casecontrol cohort (Cho et al., 2005). UCP-2 has been suggested to influence insulin secretion (Joseph et al., 2002; Zhang et al., 2001), and carriers of a UCP-2 variant are at reduced risk of developing Type 2 Diabetes (Bulotta et al., 2005). There is also a study suggesting that the mitochondrial Leucyl tRNA Synthase (LARS2) gene represents a Type 2 Diabetes susceptibility gene (t Hart et al., 2005). Together, these studies highlight the important, but as of yet unresolved, role of mitochondria in the pathogenesis of Type 2 Diabetes.

\section{Concluding remarks}

In this review, we have pointed out a number of factors and circumstances that highlight the pathogenetic role of mitochondrial perturbations in Type 2 Diabetes. They largely account for the metabolic disruption of $\beta$-cell function, a probable culprit in Type 2 Diabetes, and include 
changes in mitochondrial enzymes and structural proteins as well as mitochondrial mass and morphology. These changes are likely subject to strict genetic and epigenetic control, the latter a means whereby genetic and environmental processes converge. The future will tell if these processes have a utility as therapeutic targets in Type 2 Diabetes.

Acknowledgements: The authors thank all co-authors of their papers that have been reviewed here. The studies by the authors and which this review in part is based upon were supported by the Swedish Research Council (HM 14196 and CL 522-2006-6480), European Foundation for the Study of Diabetes/MSD (HM), the Crafoord, Wiberg, Bergvall and Albert Påhlsson Foundations, the Swedish Diabetes Association, the Faculty of Medicine at Lund University, and Lund University Diabetes Centre. 


\section{REFERENCES}

Abdul-Ghani, M.A., Tripathy, D.DeFronzo, R.A. 2006 Contributions of beta-cell dysfunction and insulin resistance to the pathogenesis of impaired glucose tolerance and impaired fasting glucose. Diabetes Care 29, 1130-9.

Ahrén, B. 2000 Autonomic regulation of islet hormone secretion--implications for health and disease. Diabetologia 43, 393-410.

Ahrén, B. 2005 Type 2 diabetes, insulin secretion and beta-cell mass. Curr Mol Med 5, 27586.

Ahrén, B., Simonsson, E., Scheurink, A.J., Mulder, H., Myrsén, U.Sundler, F. 1997

Dissociated insulinotropic sensitivity to glucose and carbachol in high-fat diet-induced insulin resistance in C57BL/6J mice. Metabolism 46, 97-106.

Anello, M., Lupi, R., Spampinato, D., Piro, S., Masini, M., Boggi, U., Del Prato, S., Rabuazzo, A.M., Purrello, F.Marchetti, P. 2005 Functional and morphological alterations of mitochondria in pancreatic beta cells from type 2 diabetic patients. Diabetologia 48, 282-9.

Barroso, I., Luan, J., Sandhu, M.S., Franks, P.W., Crowley, V., Schafer, A.J., O'Rahilly, S.Wareham, N.J. 2006 Meta-analysis of the Gly482Ser variant in PPARGC1A in type 2 diabetes and related phenotypes. Diabetologia 49, 501-5.

Bulotta, A., Ludovico, O., Coco, A., Di Paola, R., Quattrone, A., Carella, M., Pellegrini, F., Prudente, S.Trischitta, V. 2005 The common-866G/A polymorphism in the promoter region of the UCP-2 gene is associated with reduced risk of type 2 diabetes in Caucasians from Italy. J Clin Endocrinol Metab 90, 1176-80.

Butler, A.E., Janson, J., Bonner-Weir, S., Ritzel, R., Rizza, R.A.Butler, P.C. 2003 Beta-cell deficit and increased beta-cell apoptosis in humans with type 2 diabetes. Diabetes 52, 102-10.

Chan, C.B., De Leo, D., Joseph, J.W., McQuaid, T.S., Ha, X.F., Xu, F., Tsushima, R.G., Pennefather, P.S., Salapatek, A.M.Wheeler, M.B. 2001 Increased uncoupling protein-2 levels in beta-cells are associated with impaired glucose-stimulated insulin secretion: mechanism of action. Diabetes 50, 1302-10.

Chinnery, P.F., Elliott, H.R., Patel, S., Lambert, C., Keers, S.M., Durham, S.E., McCarthy, M.I., Hitman, G.A., Hattersley, A.T.Walker, M. 2005 Role of the mitochondrial DNA 1618416193 poly-C tract in type 2 diabetes. Lancet 366, 1650-1.

Cho, Y.M., Shin, H.D., Park, B.L., Kim, J.H., Park, K.S., Kim, S.Y.Lee, H.K. 2005

Association between polymorphisms in the nuclear respiratory factor 1 gene and type 2 diabetes mellitus in the Korean population. Diabetologia 48, 2033-8.

Cipolat, S., Martins de Brito, O., Dal Zilio, B.Scorrano, L. 2004 OPA1 requires mitofusin 1 to promote mitochondrial fusion. Proc Natl Acad Sci U S A 101, 15927-32.

Das, S., Bennett, A.J., Sovio, U., Ruokonen, A., Martikainen, H., Pouta, A., Hartikainen, A.L., Franks, S., Elliott, P., Poulton, J., Jarvelin, M.R.McCarthy, M.I. 2007 Detailed analysis of variation at and around mitochondrial position 16189 in a large Finnish cohort reveals no significant associations with early growth or metabolic phenotypes at age 31 years. J Clin Endocrinol Metab 92, 3219-23. 
de Andrade, P.B., Rubi, B., Frigerio, F., van den Ouweland, J.M., Maassen, J.A.Maechler, P. 2006 Diabetes-associated mitochondrial DNA mutation A3243G impairs cellular metabolic pathways necessary for beta cell function. Diabetologia 49, 1816-26.

Deng, S., Vatamaniuk, M., Huang, X., Doliba, N., Lian, M.M., Frank, A., Velidedeoglu, E., Desai, N.M., Koeberlein, B., Wolf, B., Barker, C.F., Naji, A., Matschinsky, F.M.Markmann, J.F. 2004 Structural and functional abnormalities in the islets isolated from type 2 diabetic subjects. Diabetes 53, 624-32.

Detmer, S.A.Chan, D.C. 2007 Functions and dysfunctions of mitochondrial dynamics. Nat Rev Mol Cell Biol 8, 870-9.

Ek, J., Andersen, G., Urhammer, S.A., Gaede, P.H., Drivsholm, T., Borch-Johnsen, K., Hansen, T.Pedersen, O. 2001 Mutation analysis of peroxisome proliferator-activated receptorgamma coactivator-1 (PGC-1) and relationships of identified amino acid polymorphisms to Type II diabetes mellitus. Diabetologia 44, 2220-6.

Ekstrand, M.I., Falkenberg, M., Rantanen, A., Park, C.B., Gaspari, M., Hultenby, K., Rustin, P., Gustafsson, C.M.Larsson, N.G. 2004 Mitochondrial transcription factor A regulates mtDNA copy number in mammals. Hum Mol Genet 13, 935-44.

Fex, M., Dekker Nitert, M., Wierup, N., Ling, C., Sundler, F.Mulder, H. 2007 Enhanced mitochondrial metabolism may account for the adaptation to insulin resistance in islets from high fat diet-fed C57BL/6J mice. Diabetologia 50, 74-83.

Fex, M., Wierup, N., Nitert, M.D., Ristow, M.Mulder, H. 2007 Rat insulin promoter 2-Cre recombinase mice bred onto a pure C57BL/6J background exhibit unaltered glucose tolerance. J Endocrinol 194, 551-5.

Freeman, H., Shimomura, K., Horner, E., Cox, R.D.Ashcroft, F.M. 2006 Nicotinamide nucleotide transhydrogenase: a key role in insulin secretion. Cell Metab 3, 35-45.

Frezza, C., Cipolat, S., Martins de Brito, O., Micaroni, M., Beznoussenko, G.V., Rudka, T., Bartoli, D., Polishuck, R.S., Danial, N.N., De Strooper, B.Scorrano, L. 2006 OPA1 controls apoptotic cristae remodeling independently from mitochondrial fusion. Cell 126, 177-89.

Fuku, N., Park, K.S., Yamada, Y., Nishigaki, Y., Cho, Y.M., Matsuo, H., Segawa, T., Watanabe, S., Kato, K., Yokoi, K., Nozawa, Y., Lee, H.K.Tanaka, M. 2007 Mitochondrial haplogroup N9a confers resistance against type 2 diabetes in Asians. Am J Hum Genet 80, 407-15.

Goto, Y., Nonaka, I.Horai, S. 1990 A mutation in the tRNA(Leu)(UUR) gene associated with the MELAS subgroup of mitochondrial encephalomyopathies. Nature 348, 651-3.

Handschin, C.Spiegelman, B.M. 2006 Peroxisome proliferator-activated receptor gamma coactivator 1 coactivators, energy homeostasis, and metabolism. Endocr Rev 27, 728-35.

Hara, K., Tobe, K., Okada, T., Kadowaki, H., Akanuma, Y., Ito, C., Kimura, S.Kadowaki, T. 2002 A genetic variation in the PGC-1 gene could confer insulin resistance and susceptibility to Type II diabetes. Diabetologia 45, 740-3.

Henquin, J.C. 2000 Triggering and amplifying pathways of regulation of insulin secretion by glucose. Diabetes 49, 1751-60.

Joseph, J.W., Koshkin, V., Zhang, C.Y., Wang, J., Lowell, B.B., Chan, C.B.Wheeler, M.B. 2002 Uncoupling protein 2 knockout mice have enhanced insulin secretory capacity after a high-fat diet. Diabetes 51, 3211-9. 
Kennedy, E.D., Rizzuto, R., Theler, J.M., Pralong, W.F., Bastianutto, C., Pozzan, T.Wollheim, C.B. 1996 Glucose-stimulated insulin secretion correlates with changes in mitochondrial and cytosolic Ca2+ in aequorin-expressing INS-1 cells. J Clin Invest 98, 252438 .

Lacquemant, C., Chikri, M., Boutin, P., Samson, C.Froguel, P. 2002 No association between the G482S polymorphism of the proliferator-activated receptor- gamma coactivator-1 (PGC1) gene and Type II diabetes in French Caucasias. Diabetologia 45, 602-3; author reply 604.

Lee, S., Jeong, S.Y., Lim, W.C., Kim, S., Park, Y.Y., Sun, X., Youle, R.J.Cho, H. 2007 Mitochondrial fission and fusion mediators, hFis1 and OPA1, modulate cellular senescence. J Biol Chem 282, 22977-83.

Lee, Y.J., Jeong, S.Y., Karbowski, M., Smith, C.L.Youle, R.J. 2004 Roles of the mammalian mitochondrial fission and fusion mediators Fis1, Drp1, and Opa1 in apoptosis. Mol Biol Cell $15,5001-11$.

Lindgren, C.M., Mahtani, M.M., Widen, E., McCarthy, M.I., Daly, M.J., Kirby, A., Reeve, M.P., Kruglyak, L., Parker, A., Meyer, J., Almgren, P., Lehto, M., Kanninen, T., Tuomi, T., Groop, L.C.Lander, E.S. 2002 Genomewide search for type 2 diabetes mellitus susceptibility loci in Finnish families: the Botnia study. Am J Hum Genet 70, 509-16.

Ling, C., Del Guerra, S., Lupi, R., Ronn, T., Granhall, C., Luthman, H., Masiello, P., Marchetti, P., Groop, L.Del Prato, S. 2008 Epigenetic regulation of PPARGC1A in human type 2 diabetic islets and effect on insulin secretion. Diabetologia 51, 615-22.

Ling C, D.G.S., Lupi R, Rönn T, Granhall C, Luthman H, Masiello P, Marchetti P, Groop L, Del Prato S 2008 Epigenetic regulation of PPARGC1A in human type 2 diabetic islets and effect on insulin-secretion. Diabetologia In press.

Ling, C., Poulsen, P., Carlsson, E., Ridderstrale, M., Almgren, P., Wojtaszewski, J., BeckNielsen, H., Groop, L.Vaag, A. 2004 Multiple environmental and genetic factors influence skeletal muscle PGC-1alpha and PGC-1beta gene expression in twins. J Clin Invest 114, 1518-26.

Ling, C., Poulsen, P., Simonsson, S., Ronn, T., Holmkvist, J., Almgren, P., Hagert, P., Nilsson, E., Mabey, A.G., Nilsson, P., Vaag, A.Groop, L. 2007 Genetic and epigenetic factors are associated with expression of respiratory chain component NDUFB6 in human skeletal muscle. J Clin Invest 117, 3427-35.

Lodi, R., Cooper, J.M., Bradley, J.L., Manners, D., Styles, P., Taylor, D.J.Schapira, A.H. 1999 Deficit of in vivo mitochondrial ATP production in patients with Friedreich ataxia. Proc Natl Acad Sci U S A 96, 11492-5.

Maassen, J.A., Janssen, G.M.t Hart, L.M. 2005 Molecular mechanisms of mitochondrial diabetes (MIDD). Ann Med 37, 213-21.

Maechler, P., Carobbio, S.Rubi, B. 2006 In beta-cells, mitochondria integrate and generate metabolic signals controlling insulin secretion. Int J Biochem Cell Biol 38, 696-709.

Mannella, C.A. 2006 Structure and dynamics of the mitochondrial inner membrane cristae. Biochim Biophys Acta 1763, 542-8.

Mannella, C.A., Pfeiffer, D.R., Bradshaw, P.C., Moraru, II, Slepchenko, B., Loew, L.M., Hsieh, C.E., Buttle, K.Marko, M. 2001 Topology of the mitochondrial inner membrane: dynamics and bioenergetic implications. IUBMB Life 52, 93-100. 
Mohlke, K.L., Jackson, A.U., Scott, L.J., Peck, E.C., Suh, Y.D., Chines, P.S., Watanabe, R.M., Buchanan, T.A., Conneely, K.N., Erdos, M.R., Narisu, N., Enloe, S., Valle, T.T., Tuomilehto, J., Bergman, R.N., Boehnke, M.Collins, F.S. 2005 Mitochondrial polymorphisms and susceptibility to type 2 diabetes-related traits in Finns. Hum Genet 118, 245-54.

Mootha, V.K., Lindgren, C.M., Eriksson, K.F., Subramanian, A., Sihag, S., Lehar, J., Puigserver, P., Carlsson, E., Ridderstrale, M., Laurila, E., Houstis, N., Daly, M.J., Patterson, N., Mesirov, J.P., Golub, T.R., Tamayo, P., Spiegelman, B., Lander, E.S., Hirschhorn, J.N., Altshuler, D.Groop, L.C. 2003 PGC-1alpha-responsive genes involved in oxidative phosphorylation are coordinately downregulated in human diabetes. Nat Genet 34, 267-73.

Muller, Y.L., Bogardus, C., Pedersen, O.Baier, L. 2003 A Gly482Ser missense mutation in the peroxisome proliferator-activated receptor gamma coactivator-1 is associated with altered lipid oxidation and early insulin secretion in Pima Indians. Diabetes 52, 895-8.

Muoio, D.M.Newgard, C.B. 2008 Mechanisms of disease: Molecular and metabolic mechanisms of insulin resistance and beta-cell failure in type 2 diabetes. Nat Rev Mol Cell Biol.

Nicholls, D.G. 2006 The physiological regulation of uncoupling proteins. Biochim Biophys Acta 1757, 459-66.

Oberkofler, H., Linnemayr, V., Weitgasser, R., Klein, K., Xie, M., Iglseder, B., Krempler, F., Paulweber, B.Patsch, W. 2004 Complex haplotypes of the PGC-1alpha gene are associated with carbohydrate metabolism and type 2 diabetes. Diabetes 53, 1385-93.

Poulton, J., Bednarz, A.L., Scott-Brown, M., Thompson, C., Macaulay, V.A.Simmons, D. 2002 The presence of a common mitochondrial DNA variant is associated with fasting insulin levels in Europeans in Auckland. Diabet Med 19, 969-71.

Poulton, J., Brown, M.S., Cooper, A., Marchington, D.R.Phillips, D.I. 1998 A common mitochondrial DNA variant is associated with insulin resistance in adult life. Diabetologia 41, 54-8.

Poulton, J., Luan, J., Macaulay, V., Hennings, S., Mitchell, J.Wareham, N.J. 2002 Type 2 diabetes is associated with a common mitochondrial variant: evidence from a populationbased case-control study. Hum Mol Genet 11, 1581-3.

Pratley, R.E., Thompson, D.B., Prochazka, M., Baier, L., Mott, D., Ravussin, E., Sakul, H., Ehm, M.G., Burns, D.K., Foroud, T., Garvey, W.T., Hanson, R.L., Knowler, W.C., Bennett, P.H.Bogardus, C. 1998 An autosomal genomic scan for loci linked to prediabetic phenotypes in Pima Indians. J Clin Invest 101, 1757-64.

Prentki, M.Corkey, B.E. 1996 Are the beta-cell signaling molecules malonyl-CoA and cystolic long-chain acyl-CoA implicated in multiple tissue defects of obesity and NIDDM? Diabetes 45, 273-83.

Puccio, H.Koenig, M. 2000 Recent advances in the molecular pathogenesis of Friedreich ataxia. Hum Mol Genet 9, 887-92.

Reardon, W., Ross, R.J., Sweeney, M.G., Luxon, L.M., Pembrey, M.E., Harding, A.E.Trembath, R.C. 1992 Diabetes mellitus associated with a pathogenic point mutation in mitochondrial DNA. Lancet 340, 1376-9.

Reimer, M.K.Ahrén, B. 2002 Altered beta-cell distribution of pdx-1 and GLUT-2 after a short-term challenge with a high-fat diet in C57BL/6J mice. Diabetes 51 Suppl 1, S138-43. 
Ristow, M. 2004 Neurodegenerative disorders associated with diabetes mellitus. J Mol Med $82,510-29$.

Ristow, M., Mulder, H., Pomplun, D., Schulz, T.J., Muller-Schmehl, K., Krause, A., Fex, M., Puccio, H., Muller, J., Isken, F., Spranger, J., Muller-Wieland, D., Magnuson, M.A., Mohlig, M., Koenig, M.Pfeiffer, A.F. 2003 Frataxin deficiency in pancreatic islets causes diabetes due to loss of beta cell mass. J Clin Invest 112, 527-34.

Saleh, M.C., Wheeler, M.B.Chan, C.B. 2002 Uncoupling protein-2: evidence for its function as a metabolic regulator. Diabetologia 45, 174-87.

Saxena, R., de Bakker, P.I., Singer, K., Mootha, V., Burtt, N., Hirschhorn, J.N., Gaudet, D., Isomaa, B., Daly, M.J., Groop, L., Ardlie, K.G.Altshuler, D. 2006 Comprehensive association testing of common mitochondrial DNA variation in metabolic disease. Am J Hum Genet 79, 54-61.

Saxena, R., Voight, B.F., Lyssenko, V., Burtt, N.P., de Bakker, P.I., Chen, H., Roix, J.J., Kathiresan, S., Hirschhorn, J.N., Daly, M.J., Hughes, T.E., Groop, L., Altshuler, D., Almgren, P., Florez, J.C., Meyer, J., Ardlie, K., Bengtsson Bostrom, K., Isomaa, B., Lettre, G., Lindblad, U., Lyon, H.N., Melander, O., Newton-Cheh, C., Nilsson, P., Orho-Melander, M., Rastam, L., Speliotes, E.K., Taskinen, M.R., Tuomi, T., Guiducci, C., Berglund, A., Carlson, J., Gianniny, L., Hackett, R., Hall, L., Holmkvist, J., Laurila, E., Sjogren, M., Sterner, M., Surti, A., Svensson, M., Svensson, M., Tewhey, R., Blumenstiel, B., Parkin, M., Defelice, M., Barry, R., Brodeur, W., Camarata, J., Chia, N., Fava, M., Gibbons, J., Handsaker, B., Healy, C., Nguyen, K., Gates, C., Sougnez, C., Gage, D., Nizzari, M., Gabriel, S.B., Chirn, G.W., Ma, Q., Parikh, H., Richardson, D., Ricke, D.Purcell, S. 2007 Genome-wide association analysis identifies loci for type 2 diabetes and triglyceride levels. Science 316, 1331-6.

Scarpulla, R.C. 2008 Transcriptional paradigms in Mammalian mitochondrial biogenesis and function. Physiol Rev 88, 611-38.

Scott, L.J., Mohlke, K.L., Bonnycastle, L.L., Willer, C.J., Li, Y., Duren, W.L., Erdos, M.R., Stringham, H.M., Chines, P.S., Jackson, A.U., Prokunina-Olsson, L., Ding, C.J., Swift, A.J., Narisu, N., Hu, T., Pruim, R., Xiao, R., Li, X.Y., Conneely, K.N., Riebow, N.L., Sprau, A.G., Tong, M., White, P.P., Hetrick, K.N., Barnhart, M.W., Bark, C.W., Goldstein, J.L., Watkins, L., Xiang, F., Saramies, J., Buchanan, T.A., Watanabe, R.M., Valle, T.T., Kinnunen, L., Abecasis, G.R., Pugh, E.W., Doheny, K.F., Bergman, R.N., Tuomilehto, J., Collins, F.S.Boehnke, M. 2007 A genome-wide association study of type 2 diabetes in Finns detects multiple susceptibility variants. Science $316,1341-5$.

Silva, J.P., Kohler, M., Graff, C., Oldfors, A., Magnuson, M.A., Berggren, P.O.Larsson, N.G. 2000 Impaired insulin secretion and beta-cell loss in tissue-specific knockout mice with mitochondrial diabetes. Nat Genet 26, 336-40.

Sladek, R., Rocheleau, G., Rung, J., Dina, C., Shen, L., Serre, D., Boutin, P., Vincent, D., Belisle, A., Hadjadj, S., Balkau, B., Heude, B., Charpentier, G., Hudson, T.J., Montpetit, A., Pshezhetsky, A.V., Prentki, M., Posner, B.I., Balding, D.J., Meyre, D., Polychronakos, C.Froguel, P. 2007 A genome-wide association study identifies novel risk loci for type 2 diabetes. Nature 445, 881-5.

Sun, L., Yang, Z., Jin, F., Zhu, X.Q., Qu, Y.C., Shi, X.H.Wang, L. 2006 The Gly482Ser variant of the PPARGC1 gene is associated with Type 2 diabetes mellitus in northern Chinese, especially men. Diabet Med 23, 1085-92.

t Hart, L.M., Hansen, T., Rietveld, I., Dekker, J.M., Nijpels, G., Janssen, G.M., Arp, P.A., Uitterlinden, A.G., Jorgensen, T., Borch-Johnsen, K., Pols, H.A., Pedersen, O., van Duijn, 
C.M., Heine, R.J.Maassen, J.A. 2005 Evidence that the mitochondrial leucyl tRNA synthetase (LARS2) gene represents a novel type 2 diabetes susceptibility gene. Diabetes 54, 1892-5.

Toye, A.A., Lippiat, J.D., Proks, P., Shimomura, K., Bentley, L., Hugill, A., Mijat, V., Goldsworthy, M., Moir, L., Haynes, A., Quarterman, J., Freeman, H.C., Ashcroft, F.M.Cox, R.D. 2005 A genetic and physiological study of impaired glucose homeostasis control in C57BL/6J mice. Diabetologia 48, 675-86.

Trifunovic, A.Larsson, N.G. 2008 Mitochondrial dysfunction as a cause of ageing. J Intern Med 263, 167-78.

Twig, G., Elorza, A., Molina, A.J., Mohamed, H., Wikstrom, J.D., Walzer, G., Stiles, L., Haigh, S.E., Katz, S., Las, G., Alroy, J., Wu, M., Py, B.F., Yuan, J., Deeney, J.T., Corkey, B.E.Shirihai, O.S. 2008 Fission and selective fusion govern mitochondrial segregation and elimination by autophagy. Embo J 27, 433-46.

van den Ouweland, J.M., Lemkes, H.H., Ruitenbeek, W., Sandkuijl, L.A., de Vijlder, M.F., Struyvenberg, P.A., van de Kamp, J.J.Maassen, J.A. 1992 Mutation in mitochondrial tRNA(Leu)(UUR) gene in a large pedigree with maternally transmitted type II diabetes mellitus and deafness. Nat Genet 1, 368-71.

Wikstrom, J.D., Katzman, S.M., Mohamed, H., Twig, G., Graf, S.A., Heart, E., Molina, A.J., Corkey, B.E., de Vargas, L.M., Danial, N.N., Collins, S.Shirihai, O.S. 2007 beta-Cell mitochondria exhibit membrane potential heterogeneity that can be altered by stimulatory or toxic fuel levels. Diabetes 56, 2569-78.

Vimaleswaran, K.S., Radha, V., Ghosh, S., Majumder, P.P., Deepa, R., Babu, H.N., Rao, M.R.Mohan, V. 2005 Peroxisome proliferator-activated receptor-gamma co-activator-1alpha (PGC-1alpha) gene polymorphisms and their relationship to Type 2 diabetes in Asian Indians. Diabet Med 22, 1516-21.

Wollheim, C.B. 2000 Beta-cell mitochondria in the regulation of insulin secretion: a new culprit in type II diabetes. Diabetologia 43, 265-77.

Yoon, J.C., Xu, G., Deeney, J.T., Yang, S.N., Rhee, J., Puigserver, P., Levens, A.R., Yang, R., Zhang, C.Y., Lowell, B.B., Berggren, P.O., Newgard, C.B., Bonner-Weir, S., Weir, G.Spiegelman, B.M. 2003 Suppression of beta cell energy metabolism and insulin release by PGC-1alpha. Dev Cell 5, 73-83.

Zeggini, E., Weedon, M.N., Lindgren, C.M., Frayling, T.M., Elliott, K.S., Lango, H., Timpson, N.J., Perry, J.R., Rayner, N.W., Freathy, R.M., Barrett, J.C., Shields, B., Morris, A.P., Ellard, S., Groves, C.J., Harries, L.W., Marchini, J.L., Owen, K.R., Knight, B., Cardon, L.R., Walker, M., Hitman, G.A., Morris, A.D., Doney, A.S., McCarthy, M.I.Hattersley, A.T. 2007 Replication of genome-wide association signals in UK samples reveals risk loci for type 2 diabetes. Science 316, 1336-41.

Zhang, C.Y., Baffy, G., Perret, P., Krauss, S., Peroni, O., Grujic, D., Hagen, T., Vidal-Puig, A.J., Boss, O., Kim, Y.B., Zheng, X.X., Wheeler, M.B., Shulman, G.I., Chan, C.B.Lowell, B.B. 2001 Uncoupling protein-2 negatively regulates insulin secretion and is a major link between obesity, beta cell dysfunction, and type 2 diabetes. Cell 105, 745-55.

Zhang, Y.Chan, D.C. 2007 Structural basis for recruitment of mitochondrial fission complexes by Fis1. Proc Natl Acad Sci U S A 104, 18526-30. 


\section{LEGENDS}

Fig. 1. Insulin secretion and fuel oxidation in islets from high fat diet-fed C57BL/6J

mice. Insulin secretion in response to glucose (A), $10 \mathrm{mM} \alpha$-ketoisocaproic acid (KIC), 10 $\mathrm{mM}$ methyl-succinate (Succ) (B) was determined after a 60 minute incubation of isolated islets from high fat diet (HF) and control mice (C). Oxidation of glucose, $1 \mathrm{mM}$ palmitate and $10 \mathrm{mM}$ glutamine (in the presence of $10 \mathrm{mM}$ 2-amino-2-nonbornane-carboxylic acid; $\mathrm{BCH}$ ) was determined after a 60 minute incubation of isolated islets (C-E). It is seen that insulin secretion is enhanced under $\mathrm{K}_{\mathrm{ATP}}$-independent condition (in the presence of $250 \mu \mathrm{M}$ diazoxide and $35 \mathrm{mM} \mathrm{KCl}$ ), and in response to mitochondrial fuels in $\mathrm{HF}$ islets. Metabolism of fuels other than glucose is enhanced. Data from (Fex et al., 2007).

\section{Fig 2. Schematic model for genetic and epigenetic control of mitochondrial function by} PGC-1 $\alpha$ in pancreatic $\boldsymbol{\beta}$-cells. The model is based on our findings in human islets. Thus, the nuclear-encoded gene for PGC-1 $\alpha$ is subject to both genetic and epigenetic regulation. The Gly482Ser polymorphism and methylation of the gene promoter, which are increased in individuals with Type 2 Diabetes, are associated with altered mRNA expression of PGC-1 $\alpha$ in human pancreatic islets as well as impaired glucose-stimulated insulin secretion. Met-CG is methylated CpG; TCA - tricarboxylic acid cycle; GLUT2 - glucose transporter 2. 
Fig. 1

FIGURES
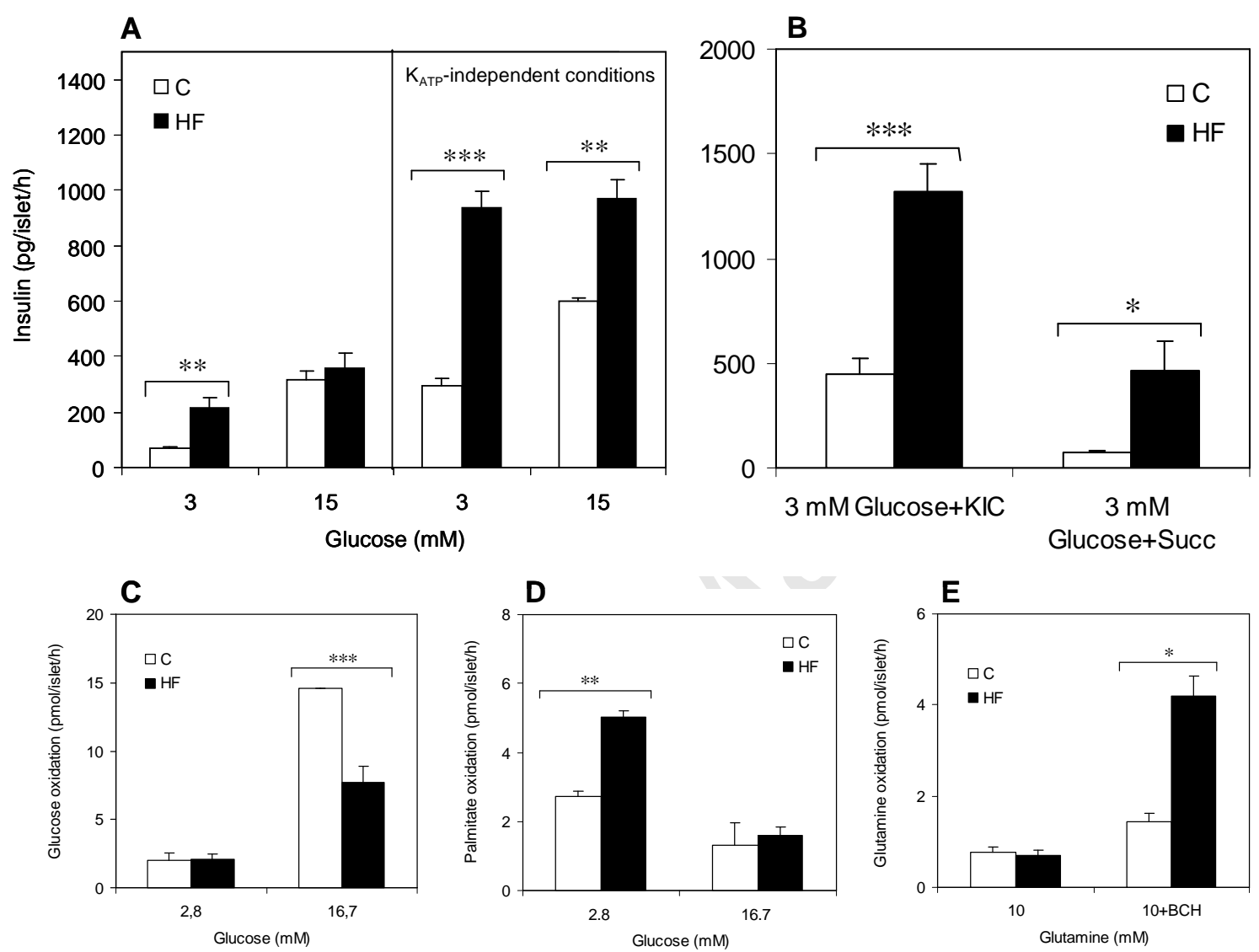
Fig. 2

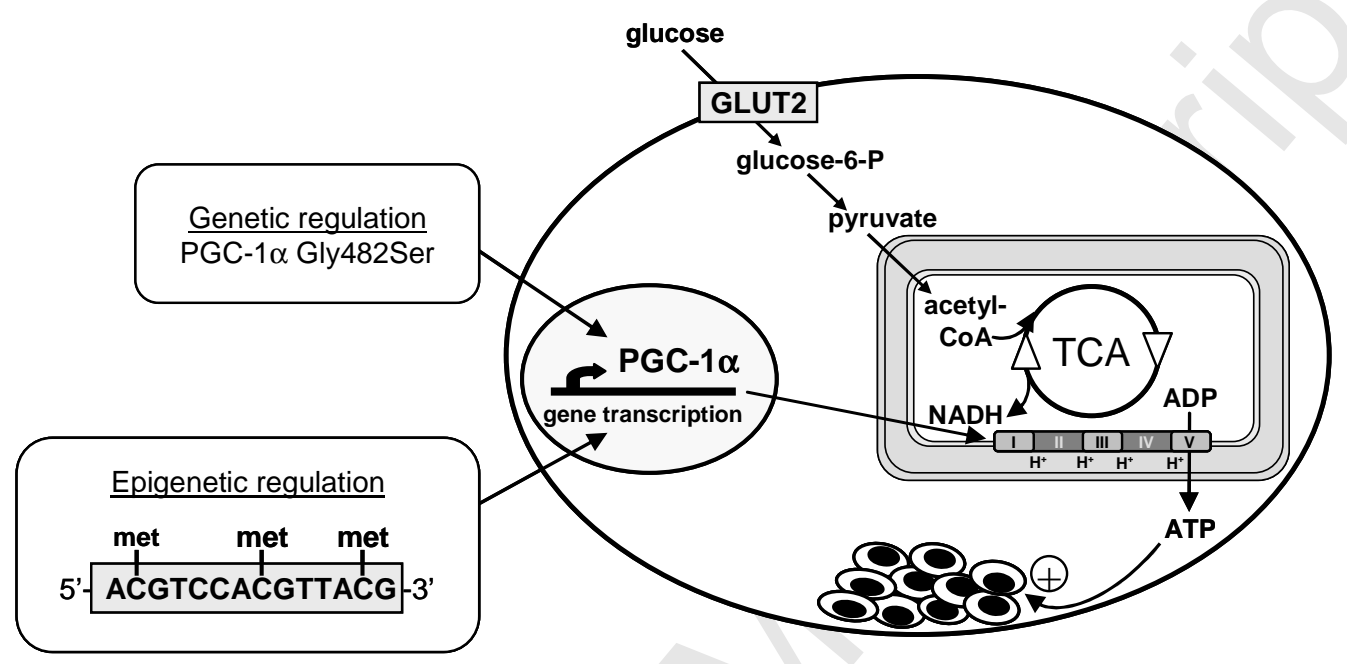

